\title{
Associate Degree Students' Attitudes Towards Distance Education at the Vocational Schools of Dokuz Eylul University
}

\author{
Kadim Ozturk \\ Buca Education Faculty, Dokuz Eylul University, Izmir, Turkey
}

\section{Email address:}

drkadimozturk@gmail.com

To cite this article:

Kadim Ozturk. Associate Degree Students' Attitudes Towards Distance Education at the Vocational Schools of Dokuz Eylul University. Education Journal. Vol. 5, No. 1, 2016, pp. 7-11. doi: 10.11648/j.edu.20160501.12

\begin{abstract}
Distance education is a generic term which includes the range of teaching and learning strategies used by higher education institutions, open universities, distance departments of conventional colleges and distance training units of conventional colleges. As educators consider implementing their traditional courses into distance learning, they should pay attention to the learning styles of the learners as well as their attitudes. The purpose of this study is to reveal the relation between university preparatory students' attitudes towards distance education at DEU and identify the factors which result in the differences in their attitudes in relation to their age, the schools they graduated from and their current level of education, which means if they take distance education classes or not. This is a descriptive study with a quantitative approach. The data were collected via the Attitudes Towards Distance Education Questionnaire from 128 students and analyzed with SPSS packet program. The results show that the students of the vocational schools tend to have rather negative attitudes towards distance education and they do not consider it as beneficial or efficient in terms of their instruction. Additionally, it has been found that their attitudes vary significantly in terms of their gender, distance education status and the type of high school they graduated from whereas there is no statistically difference in their attitudes in terms of their age.
\end{abstract}

Keywords: Attitude, Distance Education, Vocational Education

\section{Introduction}

It is true that contemporary educational processes are currently being updated. As Guri-Rosenblit (2005) points out higher education systems all over the world are constantly being challenged by the new information and communication technologies (ICT). [1] Distance education has had a remarkable effect between 1970 and 2000 and its role to complement the conventional provision is considered and studied by most governments. Johnson (2003) defines distance education as a process in which instructor and learner are separated from each other during the majority of instruction. [2] However, it differs from independent or selfdirected study in that within the body of distance learning an institution which plans curriculum exists. Daniel (1997: 15) also gives a definition of distance learning as 'the offering of educational [programs] designed to facilitate a learning strategy which does not depend on day-to-day contact teaching but makes best use of the potential of students to study on their own. [3] It provides interactive study material and decentralized learning facilities where students can seek academic and other forms of educational assistance when they need it'. Therefore, distance learning is based on the view that technology is exploited in the learning process in which learners do not have an instructor to teach them. Indeed, Moore and Kearsley (2010) suggest that distance education has attracted millions of potential distance learners in America and around the world although it has been marketed as "e-learning" or "online learning." [4]

According to Keegan (1996: 12) distance learning is based on the following premises:

- Distance education is a coherent and distinct field of educational endeavor: it embraces programs at a distance at primary and secondary, technical and further, college and university levels in both public and private sectors. It has existed for over a hundred years and is to be found today in most countries.

- Distance education is a system of education. It can provide a complete educational program for both 
children and adults outside of, and distinct from, conventional, oral, group-based provision. It has its own laws of didactical structure and its own quasi-industrial administrative procedures.

- Distance education is a form of education fraught with problems for administrators, teachers, and students. It is characterized by the fragility of the non-traditional in education. These difficulties concern the quality, quantity, and status of education at a distance. Good practice in distance education seeks to provide solutions for these inherent difficulties.

- Distance education is a needed component of most national education systems. [5]

Bates (2004: 4) suggests that distance education is one of the few areas into which technology has stepped and one of the most striking features of distance learning is that 'they are deliberately designed and structured to exploit the cost and educational benefits of technology. [6] Distance learning has therefore provided a valuable test bed for understanding the potential and limitations of a wide range of technologies in education'. Coombs (1978) also maintains that many highly developed governments and developing governments are no longer putting the money into educational buildings due to their changing political and developmental priorities. [7]

Distance education also holds a significant place in Turkey. It is not a new concept and some private educational institutions such as Limasollu Naci and FONO have started public programs for teaching English. Moreover, Ministry of National Education established the Center for Educative Films, which was later transformed into a center of production and communication which focused on radio and television programs to be used as educational aids. [8] Following these developments, the first correspondence course was commenced by the Institute of Banking and Commerce, in the year 1954, Law Faculty of Ankara University. [8] Finally, in 1982, the Ministry of National Education started the open distance education program at Anadolu University.

Currently, distance education program is becoming popular since Turkish educational environment has made efforts to become more international since 1982. [9] However, as some countries establish this system without the necessary training, instructors and practitioners alike might have to face some problems. Therefore, some extra work might be crucial in terms of cultural sensitivity of the learners to involve them in distance education programming. Within the body of this study, a descriptive study was carried out in order to diagnose the current conditions in terms of distance education programming at Dokuz Eylul University.

Research Questions

1. What are the attitudes of associate degree students' towards distance education at Vocational Schools of Dokuz Eylul University?

2. Do the students' attitudes towards distance education vary significantly in terms of

a. the type of high school they graduated from,

b. their gender,
c. their age,
d. their distance education status?

\section{Method}

This study aims to reveal the attitudes of associate degree students' towards distance education at Vocational Schools of Dokuz Eylul University and identify the factors which result in the differences in their attitudes. It can be considered as a descriptive study with a quantitative approach. Descriptive statistics tell what is there rather than trying to determine cause and effect. The purpose of a descriptive research is to describe, explain, and validate findings by describing naturally occurring phenomena without experimental manipulation which often leads a quantitative style. [10] Such type of research tends to construct statistical models and figures to explain what is observed and makes use of tools such as questionnaires, surveys, measurements and other equipment to collect numerical or measurable data. [11]

\subsection{Data Collection Instrument}

In this study, the data have been collected via the Attitudes Towards Distance Education Questionnaire developed by Ağır, Gür and Okçu (2008). [12] The questionnaire is a 5point Likert scale. There are 21 items in the attitude scale and 14 of these items are positive whereas the other 7 are negative. The participants were expected to decide to what extent they agreed with each item on a 5-point scale: (1) Strongly disagree, (2) Disagree, (3) Neither Agree Nor Disagree, (4) Agree, (5) Strongly agree. The Kaiser-MeyerOlkin coefficient of the scale (KMO) is 0.814, its significance value for the Barlett Test is 0.000 and its Cronbach-alpha reliability coefficient is 0.835 .

\subsection{Participants}

There are 6 other vocational schools in the body of Dokuz Eylül University: Justice Vocational School, Bergama Vocational School, İzmir Vocational School, HealthOccupation Vocational School and Torbalı Vocational School. The study was carried out at Torbalı Vocational School since only this school has distance learning program for its students. Therefore, 128 students at the Torbal1 Vocational School of Dokuz Eylul University participated in the study. Of the 128 participants, 52 females and 76 males did the questionnaires. They come from different types of high schools. 46 of them graduated from general high schools or general vocational and technical high schools whereas 79 of them graduated from a kind of Anatolian high school which provides students with intensive second language programs. 49 of the participant students were following a distance education program while the other 79 were having a face to face education in classrooms. Finally, 98 of the students were between 18 and 20 years old and the other 30 of them were above 21. All the background information concerning the participants is summarized in Table 1. 
Table 1. Participants.

\begin{tabular}{llll}
\hline & & Number & Percentage (\%) \\
\hline \multirow{2}{*}{ Gender } & Male & 76 & 59.4 \\
\multirow{2}{*}{ Type of high } & Female & 52 & 40.6 \\
school & General High School & 49 & 38.3 \\
& Anatolian High School & 79 & 61.7 \\
Age & $18-20$ & 98 & 76.6 \\
Distance & $21+$ & 30 & 23.4 \\
Education Status & Nos & 49 & 38.3 \\
\hline
\end{tabular}

\subsection{Data Analysis Techniques}

The data were analyzed using the Statistical Package for Social Sciences (SPSS). The statistical analysis with Means, Frequency, One Sample Kolmogorov Smirnov Test, One-way ANOVA, T-test and Mann Whitney-U test were carried out in order to find out the answers to the research questions.

One-Sample Kolmogorov-Smirnov Test was computed to test the variable is normally distributed. The results of the analysis are presented in Table 2.

Table 2. One-sample Kolmogorov-Smirnov test results for the attitudes towards distance education questionnaire.

\begin{tabular}{lll}
\hline & & $\begin{array}{l}\text { Attitudes Towards Distance } \\
\text { Education Questionnaire }\end{array}$ \\
\hline $\mathrm{N}$ & & 128 \\
Normal Parameters & $\mathrm{x}$ & 2.57 \\
& $\mathrm{ss}$ & 0.73 \\
Kolmogorov-Smirnov Z & & 0.63 \\
$\mathrm{p}$ & & $0.81 *$ \\
\hline${ }_{\mathrm{p}}<0,05$ & &
\end{tabular}

As can be seen in Table 2, the test result is not statistically significant at the $\mathrm{p}<0.05$ significance level $(\mathrm{p}=0.81)$. This means that the data are normally distributed and parametric tests can be applied in the analysis of the data.

The homogeneity of variances was tested using Levene's Test of Equality of Variances and it was found that the significance levels for "gender" $(\mathrm{p}=0.24)$ and "distance education status" $(p=0.09)$ were greater than 0.05 and these two do not violate the assumption of homogeneity of variance. However, the significance levels for "age" $(p=0.00)$ and "the type of high school" $(\mathrm{p}=0.00)$ were lower than 0.05 and these two violate the assumption of homogeneity of variance. Therefore, t-test, which is one of the parametric tests, was applied for "gender" and "distance education status" whereas Mann Whitney-U test, which is one of the non-parametric tests, was implemented for "age" and "type of high school" in order to analyze the data.

\section{Results}

The findings of the study are presented in terms of the two research questions.

1. What are the attitudes of associate degree students' towards distance education at Vocational Schools of Dokuz Eylul University?

The mean of the attitude scale is $(\bar{X}) 2.57$ and the standard deviation is 0.73 . This indicates that the participants mostly disagree with the items in the attitude scale. Therefore, it can be concluded that they tend to have rather negative attitudes towards distance education and they do not consider it as beneficial or efficient in terms of their education.

2. Do the students' attitudes towards distance education vary significantly in terms of the type of high school they graduated from, their gender, their age and their distance education status?

An independent-samples t-test was conducted to compare the learners' attitudes towards distance education in terms of their gender. The results of the analysis are given in Table 3.

Table 3. Independent t-test results for the learners' attitudes towards distance education in terms of their gender.

\begin{tabular}{lllllll}
\hline Gender & N & X & SS & Sd & t & p \\
\hline Female & 52 & 2.41 & .62 & 126 & -2.15 & $.03 *$ \\
Male & 76 & 2.69 & .78 & & & \\
\hline
\end{tabular}

$* \mathrm{p}<0.05$

As can be seen in Table 3, there is a significant difference in the scores for females $(\mathrm{M}=2.41, \mathrm{SD}=.62)$ and males $(\mathrm{M}=2.69, \mathrm{SD}=.78) ; \mathrm{t}(126)=-2.15, \mathrm{p}=0.03$. These results suggest that gender has a significant effect on the learners' attitudes towards distance education and females have more negative attitudes towards distance education than males.

An independent-samples t-test was conducted to compare the learners' attitudes towards distance education in terms of their distance education status. The results of the analysis are given in Table 4.

Table 4. Independent t-test results for the learners' attitudes towards distance education in terms of their distance education status.

\begin{tabular}{lllllll}
\hline Distance Education Status & $\mathbf{N}$ & $\mathbf{X}$ & SS & Sd & t & p \\
\hline Yes & 49 & 2.39 & .91 & \multirow{2}{*}{126} & \multirow{2}{*}{-2.30} & \multirow{2}{*}{$.02 *$} \\
No & 79 & 2.69 & .57 & & & \\
\hline
\end{tabular}

${ }^{*} \mathrm{p}<0.05$

As can be seen in Table 4, there is a significant difference in the scores for the participants having distance education $(\mathrm{M}=2.39, \mathrm{SD}=.91)$ and the ones having face to face education $(\mathrm{M}=2.69, \mathrm{SD}=.57) ; \mathrm{t}(126)=-2.30, \mathrm{p}=0.02$. These results suggest that the distance education status has a significant effect on the learners' attitudes towards distance education and the participants receiving distance education have more negative attitudes than the ones having face to face education.

A Mann-Whitney U test was conducted to compare the learners' attitudes towards distance education in terms of their age. The results of the analysis are presented in Table 5.

Table 5. Mann-Whitney $u$ test results for the learners' attitudes towards distance education in terms of their age.

\begin{tabular}{llllll}
\hline Groups & $\boldsymbol{N}$ & Mean Rank & Sum of Ranks & $\boldsymbol{U}$ & $\boldsymbol{p}$ \\
\hline $18-20$ & 98 & 64.95 & 6365.00 & & \\
$21+$ & 30 & 63.03 & 1891.00 & 1.426 & $.80^{*}$ \\
Total & 128 & & & & \\
\hline
\end{tabular}

${ }^{*} \mathrm{p}<0.05$ 
From Table 5, it can be concluded that the attitudes of the participants aged between 18 and 20 and the ones aged 21 and above are not statistically significantly $(U=1.426, p$ $=.80$ ). That is, the attitudes of the students towards distance education do not significantly differ in terms of their age group.

A Mann-Whitney U test was conducted to compare the learners' attitudes towards distance education in terms of the type of high school they graduated from. The results of the analysis are presented in Table 6.

Table 6. Mann-Whitney $u$ test results for the learners' attitudes towards distance education in terms of the type of high school they graduated from.

\begin{tabular}{llllll}
\hline Groups & $\boldsymbol{N}$ & $\begin{array}{l}\text { Mean } \\
\text { Rank }\end{array}$ & $\begin{array}{l}\text { Sum of } \\
\text { Ranks }\end{array}$ & $\boldsymbol{U}$ & $\boldsymbol{P}$ \\
\hline General high school & 49 & 52.82 & 2429.50 & & \\
Anatolian high school & 79 & 68.93 & 5445.50 & 1.348 & $.01^{*}$ \\
Total & 128 & & & & \\
\hline
\end{tabular}

$* \mathrm{p}<0.05$

From Table 6, it can be concluded that the attitudes of the participants who graduated from a general high school are statistically significantly more negative than the ones who graduated from an Anatolian high school $U=1.348, p=.01$ ). That is, the students having attended academically better schools do not have as much negative attitudes as the group having attended schools with lower levels of academic achievement.

\section{Discussion}

This study aims to reveal the attitudes of associate degree students' towards distance education at the Vocational Schools of Dokuz Eylul University and identify the factors which result in the differences in their attitudes. The results show that the students of the vocational schools tend to have rather negative attitudes towards distance education and they do not consider it as beneficial or efficient in terms of their instruction. Additionally, it has been found that their attitudes vary significantly in terms of their gender, distance education status and the type of high school they graduated from whereas there is no statistically difference in their attitudes in terms of their age.

First of all, the findings indicate that the students of the vocational schools tend to have rather negative attitudes towards distance education and they do not consider it as beneficial or efficient in terms of their instruction since they have mostly disagreed with the items in the questionnaire. Some of the participant students started having distance education within the last one year and the others had all their instruction face to face. Therefore, they might not have enough information or experience to consider all the advantages of distance education. Additionally, that they are more accustomed to face to face education might have contributed to such a hesitating and rather negative approach towards distance education. Likewise, in Birişçi's (2013) study with college students at Artvin Çoruh University, it was found that the students were undecided about the advantages of distance education although they were aware of some benefits of such an instruction. [13]

Furthermore, the findings have revealed that the learners' attitudes towards distance education vary significantly in terms of their gender, distance education status and the type of high school they graduated from. Accordingly, the males have more positive attitudes towards distance education than the females. However, in the field there are different studies with various results concerning the gender. Ateş and Altun (2008) and Süer, et. al. (2005) did not find any significant difference in the attitudes of their participants towards distance education in terms of their gender. [14, 15] Nevertheless, Horzum, Albayrak and Ayvaz (2012) conducted a similar study with teachers and found that male teachers had more positive attitudes towards distance education than females which is consistent with the findings of this study. [16] Males' general keenness on technology might have also contributed to their developing more positive attitudes towards such an instruction requiring technological literacy.

Similarly, the learners who did not receive any distance education have more positive opinions about this type of instruction than the ones who had distance education courses. This might have resulted from the fact that it was a new practice for the school which started distance education system within the last one year. Therefore, the students had to face a new experience that they were not accustomed to and tackle with some problems concerning the novelty of the system. Being more aware of the drawbacks, they might have stated more negative attitudes than the students who never had such an instruction and never experienced those difficulties. However, it could be expected as in the findings of Ateş and Altun (2008) and Ağır, Gür and Okçu's (2008) studies that the students who had familiarity with distance education or some background information concerning this type of instruction would develop more positive attitudes towards it. $[14,12]$ On the other hand, in Horzum, Albayrak and Ayvaz's (2012) research, the distance education status did not result in any significant difference in the attitudes of the participants. [16]

Another factor creating significant difference in the attitudes of the participants is the type of high school they graduated from. The students who attended an Anatolian high school had more positive attitudes towards distance education than the others. Because the students who were admitted to Anatolian high schools were required to have more academic success than the others, they could be more knowledgeable and conscious about the advantages of distance education which might have helped them to develop more positive views. Günter, Güneş and Ofluoğlu-Demir (2012) state that every member of the distance education system should receive training and gain awareness about its advantages and applications which will bear more positive opinions about it. [17]

Finally, the findings show that age does not result in any significant difference in the attitudes of the students of the vocational schools which might be due to the fact that they 
were from closer to each other in terms of their age range. Another study with pretty distinctive age groups may reveal some significant differences in the attitudes towards distance education.

\section{Conclusion}

All in all, it is seen that the students of the vocational schools tend to have rather negative attitudes towards distance education and they do not consider it as beneficial or efficient in terms of their instruction and their attitudes vary significantly in terms of their gender, distance education status and the type of high school they graduated from whereas there is no statistically difference in their attitudes in terms of their age. As Ülker-Ayyıldız, Günlük and Erbey (2006) state, there is a need for more research on the distance education in Turkey and an efficient training program both for the providers and for the recipients of this type of instruction so that a particular quality can be achieved and more positives attitudes can be developed towards distance education systems. [18]

\section{References}

[1] Guri-Rosenblit, S. (2005). 'Distance Education' and 'ELeaarning': Not the Same Thing. Higher Education. Toronto, Canada: TV Ontario.

[2] Johnson, J. L. (2003). Distance Education: The Complete Guide to Design, Delivery, and Improvement. New York; London: Teachers College Press.

[3] Daniel, J. S. (1997). Why Universities Need Technology Strategies. Change: The Magazine of Higher Learning, 29(4), $10-17$.

[4] Moore, M. G., \& Kearsley, G. (2011). Distance Education: A Systems View of Online Learning. Belmont, CA: Cengage Learning.

[5] Keegan, D. (1996) Foundations of Distance Education (3rd ed.). London: Routledge.
[6] Bates, A. T. (2004). Technology, E-Learning and Distance Education. London: Routledge.

[7] Coombs, L. C. (1977). Preferences for Sex of Children among US Couples. Family Planning Perspectives, 9(6), 259-265.

[8] Geray, C. (2007). Distance Education in Turkey. International Journal of Educational Policies, 1(1), 33-62.

[9] Ruzgar, N. S. (2004). Distance Education in Turkey. Online Submission, 5, 1-11.

[10] Seliger, H. W. \& Shohamy, E. (1989). Second Language Research Methods. Oxford: Oxford University Press.

[11] Dörnyei, Z., \& Taguchi, T. (2010). Questionnaires in Second Language Research: Construction, Administration, and Processing (2nd ed.). New York; London: Routledge.

[12] Ağır, F., Gür, H., \& Okçu, A. (2008). Uzaktan Eğitime Karşı Tutum Ölçeği Geliştirmesine Yönelik Geçerlik ve Güvenirlik Çalişmasi. E-Journal of New World Sciences Academy (NWSA), 3(2), 128-139.

[13] Birişçi, S. (2013). Video Konferans Tabanlı Uzaktan Eğitime İlişkin Öğrenci Tutumları ve Görüşleri. Journal of Instructional Technologies \&Teacher Education, 1(2), 24-40.

[14] Ateş, A., \& Altun, E. (2008). Bilgisayar Öğretmeni Adaylarının Uzaktan Eğitime Yönelik Tutumlarının Çeşitli Değişkenler Açısından İncelenmesi. Gazi University Journal of Gazi Educational Faculty (GUJGEF), 28(3).

[15] Süer, T., Kaya, Z., Bülbul, H. T., Gör, Ö., Karaçanta Ög, H., Koç, G., \& Gör, Ö. (2005). Gazi Üniversitesi'nin Uzaktan Eğitim Potansiyeli. Turkish Online Journal of Educational Technology, 4(1), 107-113.

[16] Horzum, M. B., Albayrak, E., \& Ayvaz, A. Sinıf Öğretmenlerinin Hizmet İçi Eğitimde Uzaktan Eğitime Yönelik İnançları.

[17] Günter, T., Güneş, E. Ö., \& DEMİR, E. O. (2012). Türkiye'deki Meslek Yüksekokullarında Uzaktan Eğitim. Journal of Higher Education \& Science/Yüksekögretim ve Bilim Dergisi, 2(1), 54-62.

[18] Ülker - Ayyıldız, S., Günlük, M. \& Erbey, S. N. (2006). Muhasebe Öğretim Elemanlarının Uzaktan Eğitim ve Uzaktan Muhasebe Eğitimine Yönelik Tutumları Üzerine Bir Araştırma. Muhasebe ve Finansman Dergisi, 32. 